\title{
DIGITAL TERRAIN MODEL OF THE SECOND MILITARY SURVEY - PART OF THE MILITARY TRAINING AREA BRDY
}

\author{
Martina VICHROVA, Vaclav CADA \\ University of West Bohemia in Pilsen, Faculty of Applied Sciences, \\ Univerzitni 22, Pilsen, Czech Republic \\ vichrova@kma.zcu.cz, cada@kma.zcu.cz
}

Keywords: Second Military Survey, hachure, spot height, hypsometry, digital terrain model.

\begin{abstract}
The Second Military Survey in the territories of the former Austro-Hungarian Monarchy was performed between 1806 and 1869. The territory of Bohemia was surveyed from1842 to 1852 and Moravia and Silesia from 1836 to 1840. After detailed study of the Lehmann's theory of displaying the topographic landforms using hachure's, it was detected that the hachure's in the maps of the Second Military Survey were created by means of the modified Lehmann's scale. The representation of landforms in maps of the Second Military Survey was accomplished by spot heights represented mostly by points of geodetic control. The aim of this contribution is to propose and describe the methodology of creating the digital terrain model (DTM) from the Second Military Survey hypsometry and to analyse its accuracy. A part of the map sheet (W_II_11) of the Second Military Survey, representing the long-standing military training area Brdy, was chosen as a model area. The resulting DTM was compared with the recent reference digital ground model - DMR ZABAGED ${ }^{\circledR}$. The conformity of terrain relief forms and elevation accuracy of the DTM derived from the Second Military Survey hypsometry were also investigated.
\end{abstract}

\section{HYPSOMETRY ON THE SECOND MILITARY SURVEY MAPS}

\subsection{The Second Military Survey}

The Second Military Survey (ordered by Emperor Francis II) in the territories of the former Austrian-Hungarian Monarchy progressed between 1806 and 1869. In the territories where the cadastral survey was completed (including Bohemia, Moravia and Silesia), the outcomes were exploited for the military survey. Reduced and generalised planimetric content from the cadastral maps and cadastral triangulation was used to outline the planimetric content of the Second Military Survey. This assured an improved positional accuracy and better work economy. The fundamental characteristics of original and modified surveying technologies are introduced in Table 1 . The territory of Bohemia was surveyed between 1842 and 1852 (267 handwritten colour sections 1:28 800) and Moravia and Silesia between 1836 and 1840 (146 handwritten colour sections 1:28 800), [1]. Currently, the map originals are stored in the Vienna Military archive department of the Austrian State Archives. The Second Military Survey provides a complex image of the Czech Republic before the peak of industrial and agricultural revolution. The map sheets of Bohemia, Moravia and Silesia were completed within just 16 years only. Such a quick process of mapping was possible thanks to changes in technology, especially by taking over the results of cadastral triangulation and ongoing or completed cadastral survey. The mapping work was effective, accelerated and reduced. The map sheets of Bohemia, Moravia and Silesia were prepared at the time of the onset and expansion of industrial, transport and agricultural revolutions, in the time of establishing a civil society, the rise of capitalism and the wave of urbanization. All these influences and many others influenced the image of the country and the content of the maps of the Second Military Survey. These maps still retain a great historical memory and are a valuable source of information for professional historians, archaeologists, geographers, landscape ecologists, planners, and more.

\subsection{Lehmann's theory and hypsometry on the Second Military Survey Maps}

The Saxon topographer Johann Georg Lehmann had already been concerned with the terrain representation in maps and plans since the end of 18th century. He defined, described and unified his theory, which was subsequently published in the article: Darstellung einer neuen Teorie der Bezeichnung der schiefen Flächen im Grundriß oder der Situationszeichnung der Berge, [2]. 


\begin{tabular}{|l|c|c|}
\hline \multicolumn{1}{|c|}{ Comparative characteristics } & Original concept & Modified concept \\
\hline Triangulation & military & cadastral \\
\hline System of coordinates & St. Stephen & St. Stephen, Gusterberg \\
\hline Section indexing & original & modified \\
\hline Size of one map sheet & $24^{\prime \prime} \times 16^{\prime \prime}(63 \times 42 \mathrm{~cm})$ & $20^{\prime \prime} \times 20^{\prime \prime}(52,7 \times 52,7 \mathrm{~cm})$ \\
\hline Displayed territory & $18 \times 12 \mathrm{~km}$ & $15 \times 15 \mathrm{~km}$ \\
\hline Area displayed in a map sheet & $221,0 \mathrm{~km}{ }^{2}$ & $230,2 \mathrm{~km}{ }^{2}$ \\
\hline Method of survey & Topographic survey with a plane & table \\
\hline Map drawing & $\begin{array}{c}\text { Full sections without regard to } \\
\text { provincial borders }\end{array}$ & $\begin{array}{c}\text { Only territory within provincial } \\
\text { borders }\end{array}$ \\
\hline
\end{tabular}

Table 1: Fundamental characteristics of original and modified technologies of surveying in Bohemia, Moravia and Silesia [1].

For 2D representation of terrain shapes he chose black hatches on a white background. The amount of black (the width of the hatches) on the surface was directly proportional to the value of the slope; the direction of hatches was analogous to the water flow on the surface of an elevated terrain shape. For the convenience of the topographer's work and map reading, out of the slope from the map Lehmann prepared a table with the ratios of black and white and the corresponding value of the slope between $0^{\circ}-45^{\circ}$, in increments of $5^{\circ}$. The table allowed for the estimation of the slope angle in an assigned locality by a naked eye (see Figure 1). Elevated terrain forms were surveyed from the lowest place towards the highest. At first, the horizontal lines were staked out in the terrain and then drawn into the map from the foot towards the top. Then values of the slope were recorded. Afterwards, the hachures were drawn and auxiliary drawings (horizontal lines, values of the slope) were removed in the office.

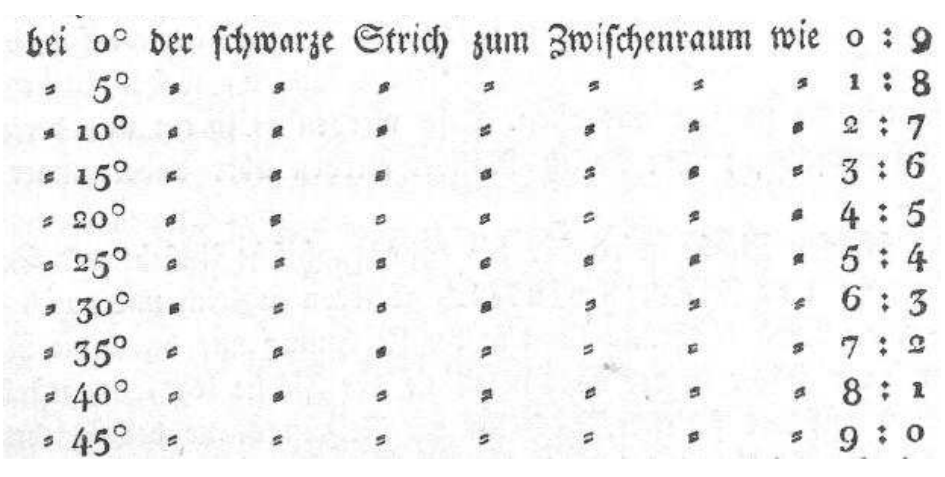

Figure 1: Ratios of black and white for the slope between $0^{\circ}$ and $45^{\circ}$ [2]

The hachures in the maps of the Second Military Survey were created by means of the modified Lehmann's scale. They portray not only the direction of the maximum gradient but also the slope of the terrain. The slope is portrayed by the functionally dependent length and thickness of the hachures, and the distances between them are according to the precise scale. The representation of the landforms in the maps of the Second Military Survey was accomplished by spot heights chosen mostly from points of geodetic control. 
The heights in the map sheets that represent territories of Bohemia, Moravia and Silesia were produced according to modified technology in units of Viennese fathoms, correct to two decimal places (see Figure 2). In the map sheets that represent a part of South Bohemia (Vitorazsko), which were made according to original technology, no spot height is available.

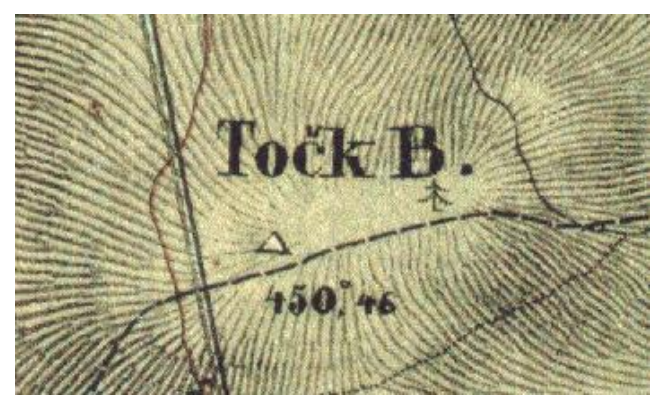

Figure 2: An example of the depiction of the spot height on the map [3].

\section{DIGITAL TERRAIN MODEL OF THE SECOND MILITARY SURVEY}

A part of the map sheet (W_II_11) from the Second Military Survey was selected as a model territory for creating the digital terrain model (DTM). This territory is situated in the surroundings of the ponds called "Padrtske rybniky" and further to the northeast of them. The chosen model territory has been part of the military area Brdy for a long time and is very sparsely populated for that reason. The territory was chosen deliberately because there are no significant changes in the terrain caused by human activities. The terrain is very diverse with some interesting morphological shapes. The area of the model territory is shown in Figure 3.

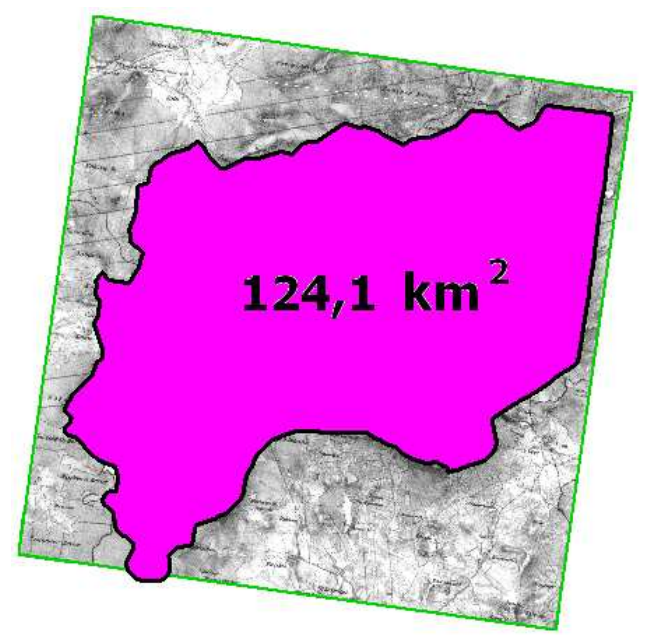

Figure 3: Model territory (a part of map sheet W_II_11) for creating the DTM [4].

The methodology for creating the DTM from hypsometry of the Second Military Survey comprises the four following steps:

1. Identification of the horizontals and skeleton elements of terrain relief in existing hypsometry,

2. fragmentation of areas with a constant slope of terrain relief,

3. determination of elevations of horizontal lines using the least squares method,

4. creation of the digital terrain model.

\subsection{Identification of horizontals and skeleton elements of terrain relief in existing hypsometry}

The skeleton elements of the terrain for the whole of the model territory (the ridge lines, fall lines, valley lines and the valley lines as a water flow) were identified and digitalized in the map using SW Kokes. Next, the boundary lines of hachure layers, recognized as the horizontal lines (see Figure 4) according to [5] were digitized. 


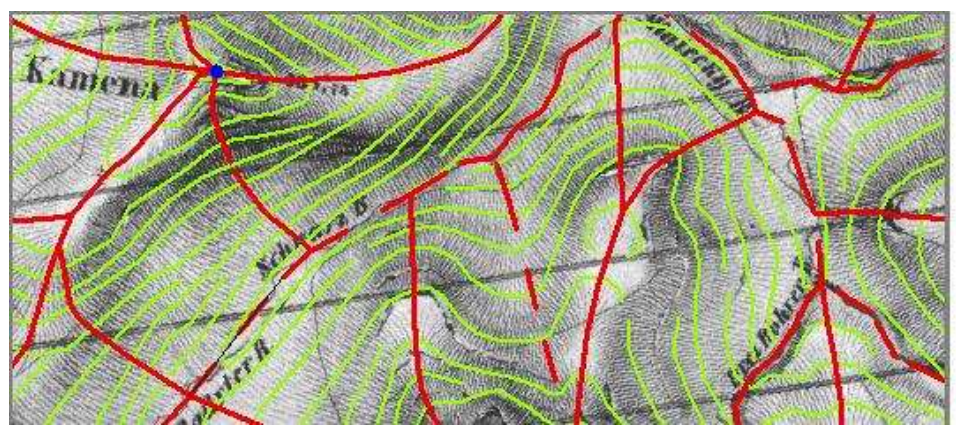

Figure 4: Horizontals (green), skeleton elements (red), trigonometric stations (blue).

\subsection{Fragmentation of areas with constant slope of terrain relief}

The fragmentation of areas with a constant slope of terrain relief comprises the six following steps:

1. Transfer of the map drawing from colour to grayscale expression,

2. adjustment and colour correction of the map drawing (with removal of some planimetric objects and descriptions from the map),

3. blurring of the map drawing,

4. setting of limits for grayscale intervals, see [6],

5. fragmentation of areas of constant slope,

6. choice of colour scale.

At first, the map drawing was transferred from colour to grayscale. Next the planimetric objects and descriptions were removed from the map and these objects were replaced by hachures similar to those in the vicinity of the object (see Figure 5). Descriptions represented in black colour would substantially skew the areas of constant slope. It was also necessary to take the colour of the background into account. Using colour histograms the background colour was set as white and the colour of hachure as black. It is obvious that leaving the planimetric objects and descriptions in the map drawing and omitting the colour correction would reduce the accuracy of the areas of constant slope and resulting digital terrain model as well.
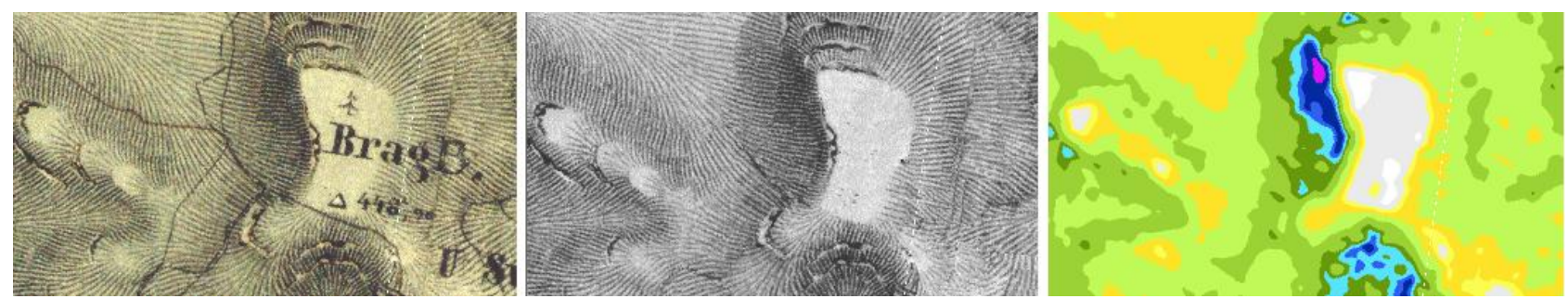

Figure 5: Original map drawing (on the left), map drawing after removing the planimetric objects and descriptions (in the middle), areas of constant slope (on the right).

\subsection{Determination of elevations of the horizontal lines using the least squares method}

Points on the borderlines of hachures (where value of the slope has changed) were identified on selected line elements of the terrain skeleton. Between such points height differences on the ridge lines, fall lines and, where necessary, on the selected valley lines were calculated using a rectangular triangle. The valley lines passing the ravine were suitable for calculating the height difference, because they respect the direction of hachure as parts of fall lines. The valley lines passing through the narrow valley, often with water flow and rocky watersides, were unsuitable for calculating the height differences. In view of the potential for discoloration or other colour changes of map drawings and background papers of old maps, it was very important to take into account the relative relations between hachure layers when 
determining the slope values. Hereafter it was very important to take into account presence of rocks and detritus fields, because these objects disturbed the areas of constant slope. Considering the local changes of hachures caused by removing some planimetric objects and descriptions from maps, it was very important to consistently follow the falling and climbing of the terrain, especially on the top parts of mountain ridges. In the next step the partial height differences were calculated between the points on the lines of the terrain skeleton on the boundary of hachure layers. Then the height differences between nodal points of the network (connected lines of the terrain skeleton) were calculated by summarising partial height differences. The complete network was adjusted by a minimum square method so that determination of the nodal point heights was not independent of the calculation mode. 133 equations were generated for adjustment of the network. The network contained 10 trigonometric stations with fixed value of their heights. 81 unknowns (heights of the nodal points) and especially the corrections $\left(\mathrm{v}_{\mathrm{i}}\right)$ for each height difference were solved for the calculation of the mean error of adjusted height difference according to (Equation 1):

$$
\mathrm{m}_{0 \mathrm{v}}=\sqrt{\frac{\mathrm{v}^{\mathrm{T}} \cdot \mathrm{v}}{\mathrm{r}}}=4.84 \mathrm{~m} \text {, }
$$

(Equation 1)

where $\vec{v}=A \cdot \overrightarrow{d h}+\vec{L}$ is the vector of height difference corrections, $v^{T}$ is the transposed vector, $A$ is the matrix of determined height difference directions, $\overrightarrow{\mathrm{dh}}=-\mathrm{A}^{\mathrm{T}} \times \mathrm{A}^{-1} \times \mathrm{A}^{\mathrm{T}} \times \overrightarrow{\mathrm{L}}$ is the vector of corrections of the approximate heights of nodal points and $\overrightarrow{\mathrm{L}}$ is the vector of height differences of nodal points.

The partial height differences summarized between the layers of hachures (on the border lines of the constant slope areas) were adjusted proportionally to the values of partial height differences. Then (proportionally to the value of slope) the height was matched to each horizontal line or a part of horizontal line that intersects the line of terrain skeleton in a concrete area. In this way, horizontal lines, parts of horizontal lines with determined heights and the heights of 10 trigonometric stations became a sufficient base for creating the digital terrain model of the Second Military Survey.

\subsection{Creating the digital terrain model (DTM)}

Horizontal lines and parts of horizontal lines with calculated heights were used for creation of the digital terrain model derived from the Second Military Survey maps. Heights displayed at 10 trigonometric stations were applied as well. The digital terrain model derived from the Second Military Survey maps was computed by means of SW MicroStation V8i - InRoads Suite. At first the triangulated irregular network (TIN) was generated and edited and then the digital terrain model (DTM) was created (see Figure 6).

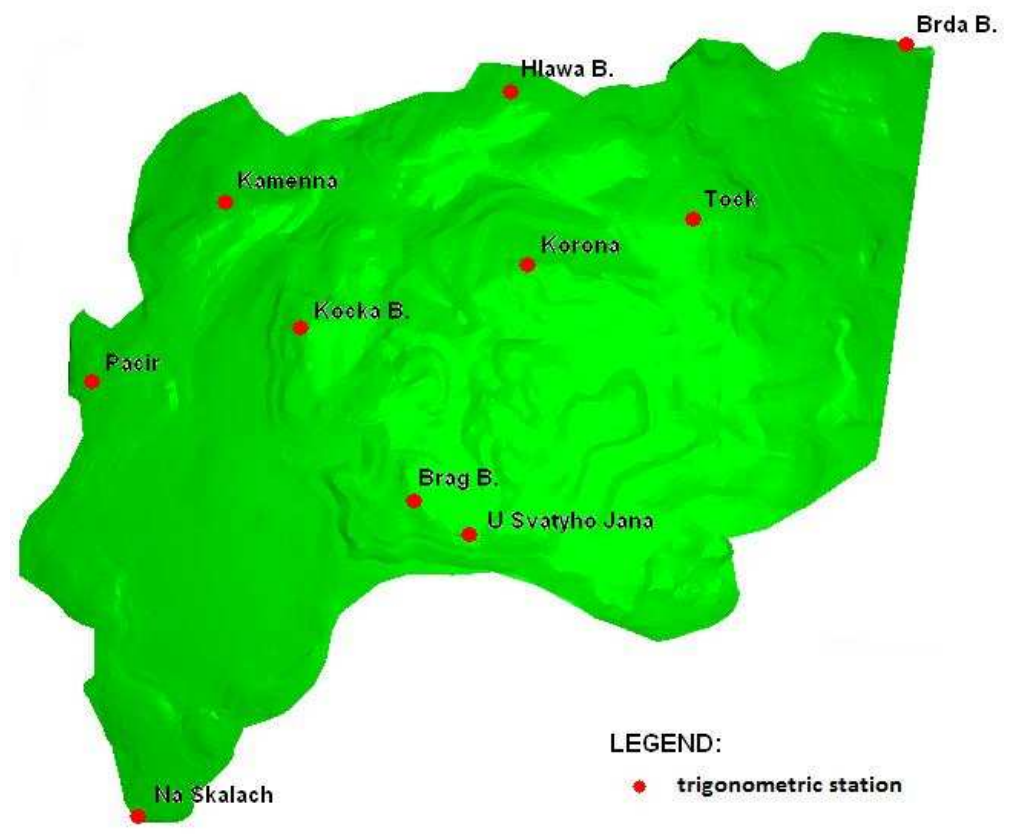

Figure 6: Digital terrain model of the Second Military Survey [4]. 


\section{COMPARING THE DIGITAL TERRAIN MODEL OF THE SECOND MILITARY SURVEY WITH THE REFERENCE DMR ZABAGED}

The digital terrain model of the Second Military Survey was compared with the recent reference digital ground model DMR ZABAGED ${ }^{\circledR}$. The Land Survey Office in Prague provided the reference data DMR ZABAGED for the model territory (3D spatial contour lines with basic interval $\mathrm{i}=5 \mathrm{~m}$, format *.dgn). According to [11], the accuracy of DMR ZABAGED hypsometry (1994 - 2000) is defined with the mean error of height $0.7-1.5 \mathrm{~m}$ in the uncovered terrain, $1-$ $2 \mathrm{~m}$ in the built-up area and $2-5 \mathrm{~m}$ in the continuous forested area; and the DMR ZABAGED improved hypsometry (since 2005) has the same parameters, but with more details. More information about accuracy of DMR ZABAGED is available in [7]. Using DMR ZABAGED hypsometry data, the reference digital terrain model in SW MicroStation V8i - InRoads Suite was derived as a generalized and edited triangulated irregular network (TIN). When comparing the reference DMR ZABAGED and digital terrain model of the Second Military Survey, it was established that both models are identical in basic forms. It is possible to see some differences in details caused by the different scale of both products (ZABAGED 1:10 000, the Second Military Survey 1:28 800) and the different representations of hypsometry on the maps. Especially the rock forms at top of elevations and terrain steps on the hillsides are represented in the maps of the Second Military Survey only schematically by hachures according to the modified Lehmann's scale and often by a map symbol. The DTM of the Second Military Survey and the DMR ZABAGED are practically identical on the hillsides and in valleys as far as terrain forms are concerned. The differential digital terrain model (DTM of the Second Military Survey minus DMR ZABAGED) was created using SW MicroStation V8i - InRoads Suite. The height differences were displayed by means of colour scale with $3 \mathrm{~m}$ (see Figure 7). Outstanding local extremes are squared off with brown lines and are numbered:

1. Local extremes caused by the positional error and especially by differences in terrain forms,

2. local extremes on the top part of the elevation caused by the incidence of rocks,

3. local extremes in the valley; it was very difficult to identify extremes from horizontal lines (the boundary lines of hachures) and to determine the slope on the lines of the terrain skeleton with sufficient accuracy because valley lines were unsuitable for such a task,

4. local extremes in places where the wrong value of the slope was determined. Probably hachures for other slopes were drawn in this place, or the wrong value of the slope was read out in the course of processing.

It is evident that the reasons of presence of local extremes could combine.

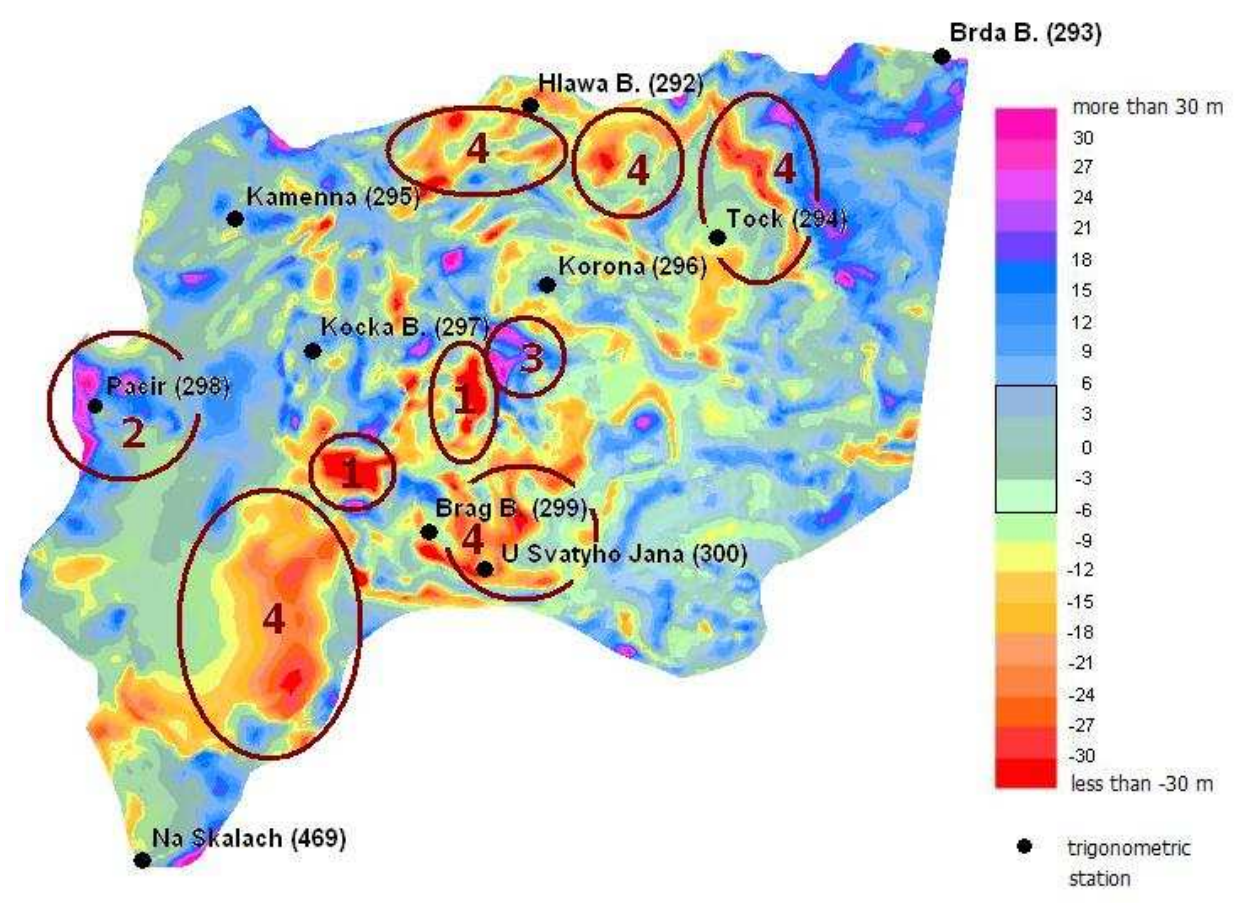

Figure 7: Differential digital model - extremes [4] (black rectangle - the accuracy of the DMR ZABAGED for continuously forested area according to [8]). 


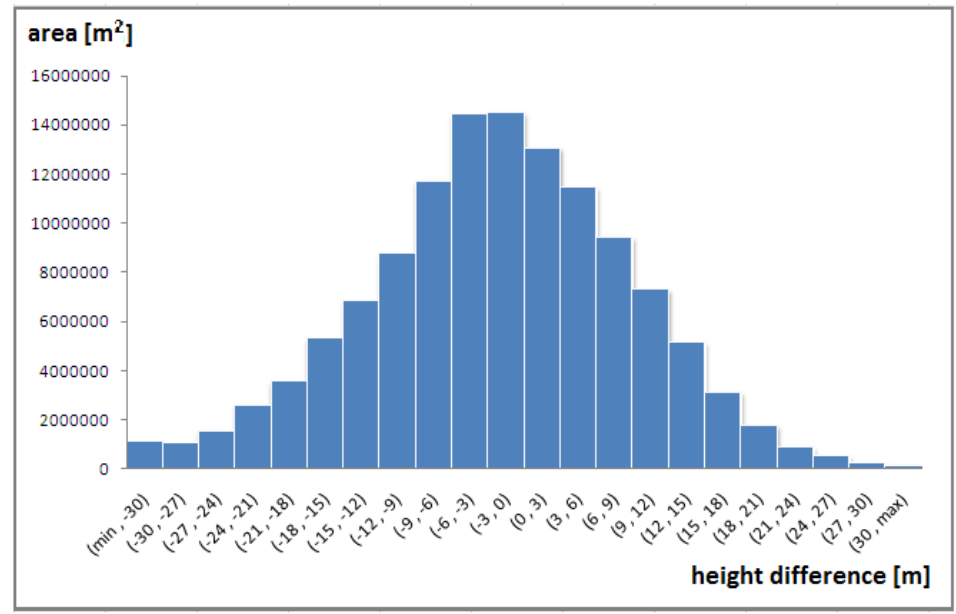

Figure 8: Areas of differential digital model for corresponding height interval in square metres [4].

Using the differential digital model, total areas for each interval of height difference were computed. The generation of the graph followed (see Figure 8). The maximum value of areas belong to intervals $(-6 ;-3)$ and $(-3 ; 0)$. The existence of a systematic error in this data set is evident. In addition, Figure 8 illustrates that the set of values is conformal with normal distribution.

\section{CONCLUSION}

The Second Military Survey maps are still very valuable and unique sources of information. They were made by unified technology using the uniform cartographic means of expression and uniform scale 1:28 800 suitable for studies of the landscape. The Second Military Survey maps provide a complex image of the countryside before the peak of the industrial and agricultural revolutions at a time when the country was not so much influenced by human activities. The described methodology of creating the digital terrain model of the Second Military Survey makes it possible to create a digital terrain model of original relief of the landscape dating back to the time of the completion of the respective map sheets (the first half of the 19th century). The method of creating the DTM of the Second Military Survey allowed us to obtain a digital model of the "previous landscape relief" anywhere in the Czech Republic that can be reliably used by many experts including geographers, landscape ecologists, historians and archaeologists. This model can be exploited in projects of revitalization of areas significantly affected by human activities such as those affected by surface mining, currently flooded areas or built-up areas, for landscape planning, implementation of landscape treatment and for landscape protection. This new method of creating the DTM of the Second Military Survey can be also used in territories where the terrain was represented only by hachures according to the modified Lehmann's scale and no heights of triangulation stations are at disposal. In such a case it is necessary to supplement the heights from other available sources (e.g. database of cadastral triangulation, spot heights in maps of the Third Military Survey or DATAZ - Database of trigonometric a densification points http://dataz.cuzk.cz/). In the case of an insufficient number of trigonometric points in the area of interest it would be necessary to determine identical points in the terrain which could be considered as position- and height- invariant since the time of creating the Second Military Survey maps.

\section{ACKNOWLEDGEMENTS}

This contribution was supported by the European Regional Development Fund (ERDF), project "NTIS - New Technologies for Information Society", European Centre of Excellence, CZ.1.05/1.1.00/02.0090.

\section{REFERENCES}

[1] Vichrova, M., Cada, V.: Altimetry on the Second Military Survey maps in the territories of Bohemia, Moravia and Silesia. The 5th International Workshop on Digital Approaches in Cartographic Heritage - Proceedings, Vienna: Resarch Group Cartography, Institute for Geoinformation and Cartography Vienna, TU Vienna. CD-ROM, 604 - 618. 
[2] Lehmann, J. G.: Anweisung zum richtigen Erkennen und genauen Abbilden der Erd-Oberfläche in topographischen Karten und Situations-Planen. Dresden, Publisher Arnold, 1812. 54.

[3] Map sheet of the Second Military Survey - W_II_11.

Österreichisches Staatsarchiv - Kriegsarchiv Wien, Kartensammlung.

(C) 2nd Military Survey, Austrian State Archive/Military Archive, Vienna.

(C) Laborator geoinformatiky, Univerzita J.E. Purkyne - http://www.geolab.cz.

(C) Ministerstvo zivotniho prosteedi CR - http://www.env.cz.

[4] Vichrova, M.: Rekonstrukce digitalniho modelu terenu druheho vojenskeho mapovani (Frantiskova). Dissertation thesis: University of West Bohemia in Pilsen, Faculty of applied Sciences - department of mathematics. Pilsen.

[5] Lehmann, J. G.: Darstellung einer neuen Teorie der Bezeichnung der schiefen Flächen im Grundriß oder der Situationszeichnung der Berge. Leipzig, Publisher Fleischer, 1799.

[6] Muster-Blätter für die Darstellung des Terrains in militärischen Aufnahms-Plänen. Zum Gebrauche der ArméeSchulen, auf Befehl und unter der Leitung des $k$. $k$. österreichischen Generalquartiermeisterstabs entworfen und mit dessen hoher Bewilligung herausgegeben (1831 - 1840). Österreichisches Staatsarchiv, Kriegsarchiv Wien. Karten- und Plansammlung, sign. KVIIa42 E.

[7] Brazdil, K.: Projekt tvorby noveho vyskopisu uzemi Ceske republiky. Geodeticky a kartograficky obzor 55 (97), 7 (2009), $145-151$.

[8] Sima, J.: Pruzkum absolutni polohove presnosti ortofotografickeho zobrazeni celeho uzemi Ceske republiky s rozlisenim 0,50, 0,25 resp. 0,20 m v uzemi na Zapadoceske univerzite v Plzni. Geodeticky a kartograficky obzor 55 (97). 9.(2009), $214-220$. 